\title{
Protestantism and Politics in Brazil: A Historical Perspective
}

\author{
Elizete da Silva (iD https://0000-0003-2343-8438 \\ State University of Feira de Santana, Brazil \\ e-mail: cliosilva@yahoo.com.br
}

\begin{abstract}
With the growth of Protestantism, changes in conceptions and in political representations have provoked participation in political parties. In 1940, evangelical parliamentarians participated in the legislature. With the military coup of 1964, Protestantism divided into one sector which joined the military, and another which resisted it and built a Protestant opposition sector, The Evangelical Bench, which aligned itself to the conservative sectors in Parliament.
\end{abstract}

Keywords: Protestantism, politics, Brazil

Słowa kluczowe: protestantyzm, polityka, Brazylia

\section{Introduction}

The presence of Protestants in the political sphere in Brazil has raised the interest of some researchers as something new or unusual. As something new, one could think of the connections those would have in partisan politics, but in their first systematic advances in the country, Protestants and Evangelicals have asserted themselves by making political articulations, establishing diplomatic relations to organize religious communities, and performing their services in a mostly Catholic religious field.

In this article, we aim to analyze the relations between Protestants and the political sectors and their social engagement. To do so, we go back to the $19^{\text {th }}$ century, when Protestantism installed, in a structured manner, its denominations in the country until the re-democratization process after 1964. Based on doctrinal principles such as a universal priesthood and free interpretation of the Bible, Protestantism is plural and presents distinct forms of apprehension of the sociopolitical reality.

We approach the Anglicans, Congregationalists and Baptists, ecumenical Protestant and progressivist sectors, as well as other recent groups like the Neo-Pentecostals 
in Brazil. The relations between religion and politics are close. Although religious groups seek eternal salvation, they do exercise devotional practices and rituals which are formed by believers and are carried out in a concrete reality while embedded in a specific historical context. Our reflections on the concept of the religious field are also based on Pierre Bourdieu. ${ }^{1}$

\section{The opening of the ports and the Brazilian religious field}

Incursions of Protestants in the Brazilian territory during the colonial times seldom occurred, and that was linked to the religious wars arising from the Protestant reform and the mercantilist policy of Europe. French Huguenots in Rio de Janeiro in the $16^{\text {th }}$ century, and Dutch Calvinists in the northeast region in the $17^{\text {th }}$ century founded ephemeral evangelical communities; the Portuguese metropolis expelled those Protestants.

A set of economic and political factors, highlighted by the opening of the ports to friendly nations in 1808 and European immigration from the Johannine period, provided an effective presence of Protestantism in Brazil. Anglicans entered the country as traders in the major cities and Lutherans arrived as small settlers in the southern regions. They founded their churches to provide spiritual assistance to the faithful followers of English and German origins, respectively.

Cornered by the continental blockade imposed by Napoleon in 1807, England found in its ally a way out: the Portuguese colony in America would be a market for its industrial production, the solution to the economic boycott imposed by France. In Bahia, the capital of Portuguese America, D. João opened the Brazilian ports "to friendly nations," that is, to England and its allies. The transfer of the Portuguese Royal Court to Brazil in 1808 caused transformations in the Brazilian religious field. As a Protestant nation, England assured its subjects would have religious privileges in the colony, which was opposed to the exclusiveness of the Catholic Church.

With the opening of the ports and guarantees of freedom of conscience, nonCatholic groups ended up enjoying prerogatives in the national territory. British colonists brought Anglicanism to Brazil. The Anglican Church had assured privileges on land. Catholicism was the official religion and Anglicanism would only be tolerated, as a minority religious group with an expressive minority of traders who, by virtue of its economic power, would cause significant changes in the local religious field.

As a church of immigrants in the Catholic hegemonic society, the Anglicans avoided confrontation with the local population. Beyond the zeal of the British consuls, by defending their fellow citizens, the Brazilian authorities were interested in preserving diplomatic relations with the British. The presence of an English colony in the country meant the existence of capital and investments as well as the presence of modern and urban enterprises. The Anglicans were affiliated with the dominant

1 P. Bourdieu, A Economia das Trocas Simbólicas, vários trad., São Paulo 1974, p. 69. 
sectors of the Brazilian economy, sharing economic power. They did not establish a political party, but actively shared in moments of power.

After the independence of Brazil, which had the decisive support of the British government, the first constitution of the country, granted in 1824 by Emperor D. Pedro I, ensured religious tolerance towards non-Catholics. Thus, it affirmed that those of religions other than that of the empire could observe their religions at home or in churches without ecclesiastical architectural structure, such as the towers and bells of the Anglican churches built along the Brazilian coast in the form of residences with Greek columns. ${ }^{2}$

In the Catholic Empire, the presence of these Protestants provoked reactions from the hierarchy of the majority church. However, the political alliances with England were strong enough to guarantee Protestants the right to worship in their own churches or designated houses for their meetings. There was also a concession for building private cemeteries, since the Catholic Church administered those already existing in the country. The British cemetery in Bahia dates from 1814.

In the second half of the $19^{\text {th }}$ century, Missionary Protestantism was established in Brazil, a result of a conjunction of factors in the historical context of the USA, which was interested in expanding trade relations. The Brazilian Empire was also interested in the coming of immigrants: the Fluminense Evangelical Church, the Presbyterian Church, and later the Methodist Church and the First Baptist Church of Brazil.

The Pentecostals, who followed a more emotional devotion as well as the glossolalia, organized themselves in Brazil at the beginning of the $20^{\text {th }}$ century. The New Pentecostals were formed in the 1970s as dissenters from the Pentecostals, and they embrace the gospel of prosperity. The God of the Kingdom Universal Church is one example.

The Protestants suffered persecutions, but they were always attentive of the political rights they had gained, and they did not stop making further claims. During the imperial period (1822 to 1889) neither the Anglicans nor other Protestants of missionary origin formed political parties. However, they did build extensive political relations, supporting groups and alliances aimed at ensuring the expansion of Protestant temples and schools.

The first Protestant missionaries, with the support of R. Kalley and Sarah Kalley, founders the Fluminense Evangelical Church of Congregational, became representatives of Emperor D. Pedro II and, diplomatically, paved the way for the first steps of Protestantism Missionary in Brazil. Mrs. Kalley set up a school and Mr. Kalley worked as a doctor, and they built space for Protestant doctrines as well as relations with the members of the diplomatic board. ${ }^{3}$ Emperor D. Pedro II, meeting the internal pressures and that of the British diplomats, signed an additional act accepting nonCatholic marriage, by instituting a record of weddings, births and deaths to whoever professed to have a religion different from that of the state.

\footnotetext{
${ }^{2}$ E. da Silva, Cidadãos de Outra Pátria. Anglicanos e Batistas na Bahia, Salvador 2017.

${ }^{3}$ L.A. Santos, Os Mascates da Fé. História dos Evangélicos no Brasil (1855 a 1900), Curitiba 2017, p. 61.
} 
With the proclamation of the Republic in 1889, the Regal Priesthood collapsed and religious freedom came to be accepted as a "must" in the country. Such a change in the religious field engendered proselytizing activities of the Protestants, causing an expansion of the society, especially among the middle and low social classes. They formed the image of peaceful people who supported the constituted authorities, according to the Bible: "The authorities that exist have been established by God" (Rom. 13:1). The Baptists criticized the Catholics for meddling in matters of political order, but the Protestants were gradually transforming apolitical thinking and searching for political insertion. Meaningful growth and the extension of civil rights came along with the Republic, providing effective conditions for Protestants to become involved in partisan politics.

\section{The first Protestant parliamentarians and the ecumenical discourse}

After the revolution of 1930, the Protestants contacted President Vargas, reaffirming the principle of religious freedom and the separation of the state. They decided to set up a cooperative entity by congregating the various denominations and marking out a space in the religious field. Presbyterian Pastor Erasmus Braga, one of the forerunners of the ecumenical movement, was concerned about political issues. $\mathrm{He}$ participated in the Congress of Panama, which preceded the creation of the Ecumenical World Council of Churches.

In 1934, the Protestants founded the Evangelical Confederation of Brazil, with the objective of preserving religious freedom in the face of Catholicism. The Baptists refused to participate. Lutherans, Anglican Episcopalians, Methodists, Presbyterians as well as Congregationalists maintained relations and internal cooperation. As for the Pentecostal groups, Foursquare Gospel Church took part from 1963, and the Pentecostal Evangelical Church Brazil to Christ from 1968.

In 1930 there was only one Protestant parliamentarian who acted in the constituent assembly of 1933, Methodist Pastor Guaracy Silveira, affiliated to the Brazilian Socialist Party. However, although as a socialist-Christian he had disagreed with the ideals of the party before the completion of the constituent assembly's works, Silveira had already followed Getulio Varga's ideas. His political performance was based on liberal practices and his focus was on the fight against the implementation of religious education, as proposed by the Catholic Electoral League.

Almeida, by studying the Protestant participation in the Constituent Assembly of 1933/1934, said: "Having [Protestantism] conquered social prestige through educational performance; partisan political action could be substantiated in guarantees for its maintenance." ${ }^{4}$ As for the implementation of religious education in the country's public schools, the left wing was defeated, despite the economic alliances with positivists, socialists and masons which the deputy Silveira had formed. From

${ }^{4}$ V. Almeida, A Participação Protestante na Assembleia Nacional Constituinte, Lima 2002, p. 2. 
a Protestant standpoint, new spaces and possibilities were opened for political action, even though they were still restricted to religious matters.

The democratic winds after 1946 motivated the participation of evangelicals in political partisanship. There were few, the Presbyterians being Antônio Queiróz, from Pernambuco, Osny Silveira from São Paulo, and Basílio Castro from Bahia. The Baptists were affiliated with the National Democratic Union. They were Augusto Paranaguá, from Piauí, Alberto Stange Júnior, from Santa Catarina, affiliated with the Democratic Republican Party, founded in 1945 by Baptist pastor José Marques, from Rio de Janeiro, who was elected a constituent assembly member in 1960.

In the 1946 legislature, the highlight in the performance of these parliamentarians was a controversy over displaying of the image of Christ in the legislative assemblies. In the midst of multiple social problems and the political attempts to reorganize the country, the focus of the evangelical members continued to be disputes with Catholicism. Topics such as freedom of conscience and services, ceremonies in cemeteries, and divorce and religious marriage were approached. In the 1950s Baptist pastor and lawyer Ebénezer Cavalcanti was elected by the National Democratic Union for the Legislative Assembly of Bahia. His legislative performance kept the focus on antiCatholicism and projects to serve the religious community.

At that time, evangelicals had not yet formed political parties, but they guaranteed spaces in the existing parties. Their ties with the National Democratic Union and Social Democratic Party can be explained by the fact that they were against communist ideas and the Americanism of traditional Brazilian politicians, which allows us to conclude that the political affiliation of the Protestants was not ideological but politically pragmatic. The electorate members were the brothers of the religious communities themselves and the vote followed the practice of society in general, which voted for names and for people and not for political programs.

The young Protestants with a more critical eye on reality also assumed the theological discourse, which nourished the participation of the evangelicals in politics. The new generation of Brazilian Protestants had a progressive conversion, not a rupture with a past, such as their parents or grandparents. In writing "converting is to abandon a speech and adopt another." Rubem Alves, a protagonist of the ecumenical group and a second-generation Presbyterian, helps us to understand the adoption of speech focused on political engagement.

In this new generation of evangelicals, due to the doctrinal accommodations to the Brazilian reality, the sectarian and proselytizing spirit of the early generations gave way, progressively, through the contextualization of the faith, to a questioning of social reality in the light of Protestant principles. They were seeking a dialogue with the world. They wanted to understand it and transform it, including by political intermediation. They were protagonists of the ecumenical sector.

In 1959, the Protestants in the country numbered 1,802,293 believers. ${ }^{6}$ Protestants were no longer a minority group in the Brazilian social structure. Many families began to have liberal professionals among them. They reached middle-class status,

\footnotetext{
${ }^{5}$ R. Alves, Protestantismo e Repressão, São Paulo 1979, p. 54.

${ }^{6}$ Statistics of the Protestant Cult in Brazil, Rio de Janeiro 1960.
} 
requiring political parity. As the other side of the coin, political prestige was a kind of bargain in which the evangelicals offered obedience to the authorities in exchange for support for the freedoms of conscience and religion.

The re-democratization of 1945 was nothing but a deception created by the state. President Dutra's government did not modify the politics: members of the Communist Party, nationalist sectors that fought for oil nationalization, and labor protestors were repressed harshly. President Vargas's tenure in 1951 was not peaceful, and he sought the support of the labor working class and the bourgeois sectors, which were favorable to the maintenance of economic areas under national control.

The tacit agreement of obedience to the authorities and neglect of the social problems was beginning to be questioned. A new generation was becoming restless with the Brazilian reality. They sought to live the Gospel in its social dimension. They were men and women of their time, a time of political transformations. In 1956 at the Congress of the Presbyterian Youth, R. Shaull spoke about the mission of the church: "In today's world, this means penetrating the basic structures of society and fighting for its transformation." "The Methodist Church published Cruz de Malta magazine, with articles addressing political issues such as the Cuban revolution, and links between the Communist Party and labor strikes. W. Cesar published in 1955 an article on the negligence of the church, When Silence is Strange. ${ }^{8}$

The youth Department of the Evangelical Confederation of Brazil met to discuss social problems and ecclesiastical issues such as the dialogue between Catholics and Evangelicals. The young Protestants participated in the Latin American Union of Evangelical Youth. Cesar was one of its directors. The University Protestant Youth was organized in the Christian Union of Brazilian Students (UCEB), congregating for Biblical studies and debates about the national reality.

In 1953, UCEB joined the International Federation of Students, an ecumenical organization. Moving away from the pietistic and conservative line, they introduced a new way of studying the Bible, updating themes in which represented the current reality in which they lived in universities and schools, and as a result it provoked a qualitative renewal among the students in the religious communities they were part of.

The UCEB published books guiding young students to a dialogue with reality. In 1953, it published Christianity and the Social Revolution by Shaull, who, at that time, was a worker of the International Federation of Students, together with the Christian Union of Students of Brazil, which made a major impact on the Brazilian evangelical community. In the introduction to the book, the author recognized: "We have not been concerned about the struggle for social justice or the meaning of the crisis of our Time."

The Protestant student movement gradually changed itself into a radiating pole of reflection and practices engaged in a political transformation. In 1956 the UCEB,

${ }^{7}$ R. Shaull, Surpreendido Pela Graça. Memórias de um Teólogo Estados Unidos, América Latina, Brasil, Rio de Janeiro 2003.

${ }^{8}$ W. Cesar, Cruz de Malta, São Paulo 1955, p. 86.

${ }_{9}$ R. Shaull, Christianity and the Social Revolution, São Paulo 1953, p. 8. 
following the example of the French working Fathers, decided to participate as workers in Vila Anastasia, São Paulo, living and experiencing the inequalities and poverty as the workers did.

On the eve of the 1955 election, Cesar wrote a Prayer for the Vote: "Lord, we are living truly cynical and sad days. It seems there is not anyone who believes, there doesn't seem to be even one person."10 Unlike fundamentalists who took refuge in piety, Cesar said: "We also confess to You, humbly, that we have failed in our political and social responsibility. As Christians, whenever we silence, we are conniving with evil." 11 As the vote in Brazil was mandatory, some Protestants exercised their citizenship just by going to the polls to vote.

Cesar led the Church and Society Sector, created by the World Council of Churches in 1955 and assumed by the Evangelical Confederation of Brazil. That was boosted by the "imperative need to study on the implications of our faith in the troubled national scenario. Examining the evangelizing and social work in the face of new and revolutionary aspects for the society in which we live."12

The committee organized four national conferences with the aim of understanding the country's reality and of offering prospects. The first conference took place in 1955, in São Paulo, called Consultation on the Social Responsibility of the Church. The second meeting on the social responsibility of the church was held in Campinas. About the Protestants' participation in political parties this was suggested: "encouraging evangelicals to participate in the political life of the country by means of partisan affiliation and action within the existing parties." There was a new perspective for politics: "educating evangelicals to consider the political vocation of believers as a noble and worthy vocation." 13

The third Conference on Social Responsibility of the Church took place in 1960. The political and social framework of the country was based on the national industrializing euphoria of the years of President Kubitschek. In fact, it was a social politics of inequalities and the Protestant leaders were aware of this reality.

The fourth conference of the Church's Social Responsibility sector took place in Recife, in 1962, under the theme Christ and the Brazilian Revolutionary Process. It was known as the Northeast Conference, in a region of social conflicts, aggravated by secular structural problems. The creation of Northeast Development Agency in 1959 did not solve the problems of the northeast. In rural areas, workers clashed with the powerful landowners. The peasant leagues led by Francisco Julião increased in the 1960s in Pernambuco, where Reverend João Dias de Araújo, an ecumenical Presbyterian, supported the movement.

With the outbreak of the military coup in 1964, which installed a military dictatorship in the country, the Evangelical Confederation of Brazil was decommissioned and the Social Responsibility Sector of the Church disbanded itself and several of its

\footnotetext{
10 W. Cesar, op. cit., p. 43.

11 Ibidem.

12 Annals of the III Meeting of the Sector Church and Society, 1960. p. 1.

13 Report of the II Conference. Evangelical Confederation of Brazil, 1962.
} 
leaders. César and Araújo were persecuted by the security agencies of the military dictatorship as suspected subversives. The ecumenical group suffered persecution and several young people, such as Rubem Alves, were forced into exile.

\section{Protestants, dictatorship and re-democratization}

In the face of the military dictatorship, the Protestants split into two camps: those who joined it, thinking that the military system would save Brazil from atheistic communism, and those who opposed the arbitrariness of the regime, who were a minority in their religious groups. They condemned the "materialistic atheism" claimed by the communist leaders, who had an objective to "uproot the idea of God of the human heart." 14

In the Presbyterian Church, anti-communism was another reason to support the dictatorship, and for some brothers of the community itself to denounce other members, viewed as atheistic Marxist. On March 31, 1964, Reverend Araújo reported that Reverend Israel Gueiros, who was on the radio program at Pernambuco Radio Club "thanked God for the military scammers and denounced that there was a Marxist Protestant Professor, João Dias de Araújo, at the North Presbyterian Seminary, in Recife."15

Pastor Gueiros was the leader of the Presbyterian Fundamentalist Movement, which was radically opposed to ecumenism embraced by the professor of theology. Gueiros continued in his denunciations against the Reverend Araújo "accusing him of inciting young seminarians to communist ideas." Denounced by his brother of faith, the Reverend Araújo was called by the Police Department of Political Security to explain the denunciations. The text of the project named Brazilian Never More mentions that the anti-communist propaganda was conveyed "by the bodies financed by the United States the Social Democratic Party, the National Democratic Union and the Catholic Church." ${ }^{16}$ The most recent research reveals that the Protestant sectors became effective anti-communism preachers. ${ }^{17}$

For the supporters of the dictatorial regime, the military system was a divine instrument against the "red danger" which was threatening the country and religious freedom. In Recife, the fundamentalist evangelicals performed services in thanksgiving, at the temple of the Fundamentalist Presbyterian Church, led by the Reverend Gueiros in a manifest of support for the armed forces. In 1970, Valdívio Coelho, chaplain of the army and pastor of the Baptist Church Zion in Salvador, Bahia performed services by the "Miracle of God to have preserved Brazil from communism." The services were held at Castro Alves Theater, with the presence of hundreds of military and Baptist brothers.

14 "O Jornal Batista," 3.05.1964, p. 6.

${ }^{15}$ Interview granted to the author on 26 November 2013.

${ }^{16}$ Archdiocese of São Paulo, 1985, p. 59

${ }^{17}$ L.S. Almeida, "O comunismo é o ópio do povo": Representações dos batistas sobre o comunismo, o ecumenismo e o governo militar na Bahia (1963-1975), MA dissertation in History, State University of Feira de Santana, Reclife 2011. 
The Cold War between the USA and the countries of the Communist Bloc should be considered in the process of legitimizing the 1964 coup. The Brazilian Protestants had spiritual and ideological ties with their brothers in the USA. The United States, opposed to socialism and mentoring several coups and military governments in Latin America, was also an evangelical nation that sent missionaries to Brazil. The United States was the "implicit utopia of Brazilian Protestantism," 18 as asserted by Alves.

Governor Antonio C. Magalhães, representative of the dictatorship in Bahia nominated the Baptist Cleriston de Andrade as Mayor of the City of Salvador in 1979. He consolidated a long alliance between the Baptist leadership and the representatives of the military government in Brazil intermediated by the federal representative of the ARENA party, Raimundo Brito, who was Pastor Coelho's brother-in-law.

Evangelical opponents of the military regime suffered persecution within the communities themselves, as well as at the hands of the government's repressive agencies. Others were assassinated, such as Paul Wright, a militant of the Popular Action and a deputy in Santa Catarina, who was impeached in 1964, was clandestine in Cuba and returned to clandestine activity in Brazil, continuing in the Popular Action until his disappearance. In 1964 Paul Wright, as a refugee at the Mexican Embassy, sent a letter to Reverend J. Wright, his brother, reaffirming his commitment: "I write these things to let you know that I do not regret anything I did and I do not intend to give up the fight I started in obedience to the call of our common Lord." 19

Some Protestants joined the Communist Party of Brazil, such as Norberto Bishop S. Filho, who became a member on July 2 at Baptist Church in Salvador, directed by Pastor Cavalcanti. He was part of a group of activists in the 1960s, but he was not arrested, as he died before the police searched his residence and threatened the family members. According to his sister, Professor, Ellen Melo, the same "did not take the pressure and asked for his removal from the church, before they eliminated him, the church did not support politics, or subversives." ${ }^{20}$

On becoming victims of repression, the progressist evangelical segment sought other political alternatives. In 1973, the churches participating in the World Council of Churches organized the Ecumenical Service Coordination (CESE), headquartered in Salvador, with a proposal for cooperation among Brazilian evangelicals. It proposed social service for the impoverished, and support to social movements with an ecumenical vision of respect for the religious diversity of the country.

The kind of service that presided over the actions of the founders of the CESE was part of a Christian vision of the Social Gospel or Barthian theology, in which the Gospel is for man in his totality, not only for future salvation. Jaime Wright, a progressist Presbyterian engaged in this perspective, expressed himself: "The church must take care not only of the salvation of the soul, but of the man as a whole, to give him living conditions to integrate actively into the context of society." ${ }^{21}$

\footnotetext{
${ }^{18}$ R. Alves, op. cit., p. 239.

19 D.J. Wright, O Coronel Tem um Segredo: Paulo Wright não está em Cuba, Petrópolis 1993, p. 49.

${ }^{20}$ Interview with the author, 3.03.2007.

21 "Tribuna da Bahia," 15.07.1974, p. 3.
} 
The first national project that the CESE sponsored was a Human Rights Campaign, initiated in 1973, during the military dictatorship. CESE was one of the first Brazilian organizations to have a systematic strategy to fight for Human Rights at the time. The sociologist César was one of the authors of the project, which included lectures and support for groups, as well as the publication of the integral text of the Universal Declaration of Human Rights, in the form of a booklet. ${ }^{22}$

The articles of the Universal Declaration of Human rights were presented, accompanied by biblical texts. The presentation of article I: "All men are born free and equal in dignity and rights. They are endowed with reason and conscience and must act in relation to one another with a fellowship spirit." ${ }^{23}$

Reverend Wright participated in the project on Human Rights, also becoming one of the executors of the Brazil Never Again movement, along with Catholic leaders such as D. Paulo E. Arns, archbishop of São Paulo. Wright was responsible for the $4^{\text {th }}$ edition of the booklet in 1977. Between 1973 and 1978, 1.8 million copies of the booklet were published. A Brazilian project, Brazil Never Again, in its defense of Human Rights and against the violence of the military government, counted on the financial contribution of the World Council of Churches and the CESE.

CESE supported the creation of committees that fought for the amnesty of political prisoners in Brazil. In 1982, it funded the creation of the National Human Rights movement in Brazil, the Southern Cone Project, supporting Latin-American exiles persecuted in their home countries. An eloquent example of the action of this CESE project was the massacre of inmates in Carandiru Prison in São Paulo in 1992, when the survivors, crying out loud in despair, held a copy of the Human Rights booklet, published by the agency. Those men were just fighting for the most basic Human Right: the right to life, to their own existence.

The process of re-democratization in the country was slow. At the beginning of the 1980 s, the constituent assembly and new political parties were formed. The Baptist newspaper of 1986, published the article The evangelicals and the Constituent Message to the evangelicals and the Brazilian people, a manifesto on the necessity of the Evangelicals' actions in the constituent assembly, taking into account the expressiveness, which the Protestants had in Brazil. ${ }^{24}$

The trajectory of Presbyterian Reverend Celso Dourado led to his participation in partisan institutions. He became a council member in Campo Formoso with the Brazilian Labor Party. With the dissolution of the political parties by the Institutional Act No. 2, in October 1965, he participated in the organization of the Brazilian Democratic Movement, a party in opposition to the military regime.

The brothers of the Church of God's Assembly also applied for political office, abandoning the thought that politics was sinful. The thesis "brother votes in brother," defended by Josué Sylvestre in his book, Irmão Vota em Irmão: os evangélicos, a Constituinte e a Bíblia ${ }^{25}$ was proven in several Protestant communities. Deputies

\footnotetext{
22 "Minute Book. Ecumenical Service Coordination's minutes" 1973, no. 3, p. 4.

${ }^{23}$ Ecumenical Service Coordination, The Universal Declaration of Human Rights, 2000, p. 3.

24 "O Jornal Batista," 12.01.1986, p. 2.

25 J. Sylvestre, Irmão Vota em Irmão: os evangélicos, a Constituinte e a Bíblia, Pergaminho 1986.
} 
were elected in Bahia like Eliel Santana and Milton Barbosa of the Brazilian Democratic Movement. They subsequently transferred to the Liberal Front Party and, in 2005, to the Christian Social Party; Gerson Gomes, alderman in Feira de Santana of the Brazilian Democratic Movement was reelected, and he later moved to the Liberal Front Party.

As for the Christian Social Party, it is necessary to highlight that while Christianity and Christian social doctrine appear as a programmatic basis, "where Christianity, more than a religion, represents a state of mind that does not segregate, it does not exclude, nor discriminate, but which accepts all, regardless of creed, color, race, ideology, sex, social status," Art. 2 of the Christian Social Party. ${ }^{26}$ In fact, it has been a political party controlled by the God Assembly since its founding in 1985.

Partisan infidelity has been a constant among evangelical politicians, which demonstrate pragmatism without much ideological or programmatic consistency. The trajectory of Eliel Santana allows such confirmation: the son of Pastor Rodrigo Santana, leader of the God Assembly in Bahia, he was a council member for the Renewing Labor Party. He defected to the party of the Brazilian Democratic Movement and was elected, but resigned and was elected State Deputy to the Legislative Assembly of Bahia (1999 to 2003) as a member of the Brazilian Socialist Party. In 2007, he was elected representing the Christian Social Party.

Progressist Protestants formed with Catholics from the Basic Communities Ecclesial and Pastoral, as it was called by the churchmen of the Labor Party, founded in 1980, with a platform focused on workers and the end of the military dictatorship. In 1989, the Labor Party launched the candidacy of Lula da Silva for the presidency of the Republic. Evangelical committees were formed to support Lula's candidacy and several evangelicals applied for the executive and legislature in the country. The Labor Party had a political agenda focused on the social minorities.

Two Evangelical politicians represented the division in the Baptist denomination: Walter Pinheiro represented the progressivist wing, aligned with the Labor Party opponents of the military Regime; Gerson Gabrielli was part of a Conservative party, the Liberal Front Party led by Antonio C. Magalhães. The conservative segments of Protestantism also aligned themselves with the traditional parties; they applied for the executive and legislature in various regions of the country, and were subsequently linked to the evangelical committee led by church politicians from the Universal of the Kingdom of God, founded in 1977 by Edir Macedo.

At the beginning of the 1990s, Protestants linked to the Biblical University Alliance of the Labor Party, led by Robinson Cavalcanti, organized the Progressive Evangelical Movement. Cavalcanti, an Anglican Bishop, was a professor of Political Science and he wrote the book Christianity and Politics in 1985, a work that provoked many debates among evangelical universities and the older generation.

In the late 1990s, the Universal Church of the Kingdom of God, of Neo-Pentecostal doctrine, focused on the political participation of its speeches and articles in the Universal Journal, justifying the vocation of the "Politicians of Christ," and

${ }^{26}$ Art. 2 of the Statut of Christian Social Party (PSC), http://www.psc.org.br/wp-content/uploads/2017/07/Estatuto-PSC_pdf-2019.pdf [access: 1.09.2018]. 
defending the systematic insertion of Evangelicals in the institutions of power. It created an internally political organization, under the charge of Bishop Carlos Rodrigues, who published three booklets entitled: The Church and Politics, The Church and the Social, and The Church and the Media, supporting the interventions in politics with biblical issues.

After the elections of 1994, the number of Protestant politicians grew exponentially and they formed a parliamentary bench composed only of Evangelicals, according to Senator Pinheiro "not using Christianity as a basis for life guidance, but the Gospel as an instrument of bargaining." 27 The evangelical bench was a very heterogeneous group, led by the Universal Church of the Kingdom of God and another Neo-Pentecostal Church, which aligned themselves with the most conservative sectors. "This type of evangelical project was a winner because it was in the context of a Brazilian political culture, where the bargaining and the use of the institutions to achieve personal advantages (or the religious group) were present in a striking way." 28

As politics is the art of the possible, the Neo-Pentecostal stream awakened the electoral greed of a small party, which was designated as classist and socialist. As it approached the Labor Party, the Universal Church of the Kingdom of God made criticism against Lula da Silva, calling him the "bearded devil," in the elections of 1989, and after negotiations the Liberal Party, with the Universal Church of the Kingdom of God, allied itself with Labor Party and in 2002, the Vice-President of the Republic was the entrepreneur José Alencar.

In 2005, the Liberal Party merged with another college and became the Party of the Republic, linked to the Universal Church of the Kingdom of God. Several ministers of Lula da Silva and Dilma Rousseff's government were from the Universal Church of the Kingdom of God, such as Marcelo Crivela, Minister of Fishing and Agriculture. Today, he is the mayor of Rio de Janeiro.

\section{Final considerations}

The growth of Protestant institutions provoked participation in political parties. Thus, the military coup of 1964 divided the country. Protestantism divided because of the dictatorship: one sector joined the military faction, while another minority group resisted. The bodies of the ecclesiastical hierarchy officially supported the military government, but contrary segments have made intense opposition to the military regime.

Pleading for re-democratization and human rights in the country, the Ecumenical Coordinator of Services with the collaboration of the World Council of Churches had a relevant role, including refuge for Brazilians persecuted by the military regime, such as Professor Paulo Freire. That evangelical ecumenical segment that resisted the dictatorship participated in the Commission of Truth.

${ }^{27}$ Interview by Senator Walter Pinheiro, 18.09.2011.

28 A.M. Santos, E o Senhor Te Porá Por Cabeça E Não Por Cauda: A Participação Evangélica Na Politica Baiana 1986-2002, PhD thesis in History, Faculty of Philosophy and Human Science, Federal University of Bahia, Salvador 2017, p. 87. 
The plurality of Protestantism caused a diversity of political positions. In the opposition to President Rousseff, several evangelicals supported the coup of 2014 and others organized the Evangelical Front by the Rule of Law, defending democracy against the impeachment of the president. In 2010, Protestants numbered 42.3 million believers among the population of the country. This quantitative growth intensified the participation of evangelicals in political partisanship.

\section{References}

Almeida L.S., "O comunismo é o ópio do povo”: representações dos batistas sobre o comunismo, o ecumenismo e o governo militar na Bahia (1963-1975), MA Dissertation in History, State University of Feira de Santana, Recife 2011.

Almeida V., A Participação Protestante na Assembleia Nacional Constituinte, Lima 2002.

Alves R., Protestantismo e Repressão, São Paulo 1979.

Araújo J.D. de., Documentos da Confederação Evangélica do Brasil, Recife, 1962.

Arquidiocese de São Paulo, Brasil Nunca Mais, Petrópolis 1986.

Bourdieu P., A Economia das Trocas Simbólicas, vários trad., São Paulo 1974.

Cesar W., Cruz de Malta, São Paulo 1955.

"Minute Book. Ecumenical Service Coordination's minutes," 1973, no 3.

Santos A.D.M., E o Senhor Te Porá Por Cabeça E Não Por Cauda: A Participação Evangélica Na Politica Baiana 1986-2002, PhD thesis in Human Science and Philosophy, Federal University of Bahia, Salvador 2017.

Santos L.A., Os Mascates da Fé. História dos Evangélicos no Brasil, 1855 a 1900, Curitiba 2017.

Shaull R., Christianity and the Social Revolution, São Paulo 1953.

Shaull R., Surpreendido Pela Graça. Memórias de um Teólogo Estados Unidos, América Latina, Brasil, Rio de Janeiro 2003.

Silva E. da, Cidadãos de Outra Pátria. Anglicanos e Batistas na Bahia, Salvador 2017.

Silva E. da, Protestantismo Ecumênico e realidade brasileira: Evangélicos Progressistas em Feira de Santana, Feira de Santana 2010.

Statistics of the Protestant Cult in Brazil, Rio de Janeiro 1960.

Sylvestre J., Irmão Vota em Irmão: os evangélicos, a Constituinte e a Bíblia, Pergaminho 1986.

Wright D.J., O Coronel Tem um Segredo: Paulo Wright não está em Cuba, Petrópolis 1993. 